\title{
MINDREADING
}

\section{The Quantity Theory of Insanity by Will Self}

\section{Stephen Ginn}

Stephen Ginn is an ST5 in general adult psychiatry, East London NHS Foundation Trust, UK.

Correspondence Dr Stephen Ginn, Donald Winnicott Centre, Coate Street, London E2 9AG, UK. Email: mail@stephenginn.com a. The biographical details in this essay are from Hunter Hayes 2007.

\begin{abstract}
SUMMARY
The Quantity Theory of Insanity is a short story by the English novelist and journalist Will Self. It is one of six stories in a collection of the same name. Its central conceit is that there is 'only a fixed proportion of sanity available to any given society at any given time'. The story is a broad satire of academia, social science and our treatment and understanding of mental disorder.
\end{abstract}

\section{DECLARATION OF INTEREST}

S.G. has met Will Self on one occasion and interviewed him for his personal blog.

Will Self was born in London in 1961 and grew up in the London suburb of East Finchley. ${ }^{a}$ His mother was a Jewish American publishing assistant with a love of literature; his father a professor of public administration at the London School of Economics. His parents separated during Self's adolescence, their relationship having been one of mutual animosity for some years.

Self was precociously intellectual, and read voraciously during his youth. During his teenage years his admiration of American Beat writers such as William Burroughs provided some justification for his developing drug habit. He began smoking cannabis at 12 years old and injecting heroin at 17. Going up to Oxford in 1979, Self read politics, philosophy and economics. He achieved only a third-class degree, having been arrested for drug possession just before his final examinations.

Following graduation, Self worked in a number of jobs. Unable to find a publisher for his fiction, he began publishing a cartoon in the New Statesman. This ran regularly for 2 years, but was eventually discontinued because of its downbeat nature. In 1986, at his mother's expense, he began treatment for alcohol and drug dependency. Following this, Self abstained for 3 years but relapsed in 1989, after his manuscript for The Quantity Theory of Insanity was accepted for publication. Notoriously, while covering the 1997 UK election campaign for The Observer newspaper, Self took drugs on Prime Minister John Major's jet (Barber 2000). He was dismissed from the newspaper and was treated for substance misuse for a second time.
During a career now spanning over 20 years, Self has published seven novels and six collections of short stories. He is also well known as a broadcaster and cultural critic. In February 2012, he was appointed Professor of Contemporary Thought at Brunel University.

\section{The Quantity Theory of Insanity}

The Quantity Theory of Insanity is a collection of six short stories (including a short story with the same title) first published in 1991. It takes the form of a 'fractured novel' (Hunter Hayes 2007) and, although each story is self-contained, in some respects the narratives overlap. The themes explored by the collection's stories, most notably mental illness and drugs, continue to be reflected in Self's more recent work (Hunter Hayes 2007).

The Quantity Theory of Insanity is representative of Self's subsequent style, which often combines theatrical writing and the inclusion of a broad range of literary and philosophical touchstones into stories set in bizarre, but nonetheless recognisable, alternative realities. Alongside Ward 9, another story in the collection, The Quantity Theory of Insanity also marks the debut of Self's longest running character, Dr Zac Busner. Busner is a London-based psychiatrist and psychoanalyst, inspired in part by R. D. Laing and Thomas Szasz (Oyebode 2010). By repeatedly revisiting Busner's character, Self's intention is to 'examine in fictional terms the role of the psychiatrist in our culture and what the psychiatrist represents' (Oyebode 2010).

\section{Synopsis}

The story is narrated by Harold Ford, the originator of the 'quantity theory of insanity', as he prepares to speak at a conference where all the theory's original investigators will be present. Although the theory has brought him fame, he has become disillusioned with the 'great industry' that has emerged as a result of it. With the aim of explaining how the theory came into being, Ford narrates a scientific and personal biography.

After a 'spectacularly mundane' upbringing and a childhood of 'Terylene sheets, bunion plasters and Sunday afternoon excursions to witness the 
construction of Heathrow Airport', Ford becomes obsessed during his teens with the theoretical aspects of psychology. In Chelmsford, studying phrenological and physiognomic theories of the 19th century, he meets by chance Dr Alkan, a psychiatrist and psychoanalyst.

Alkan becomes Ford's supervisor, although Ford's role is closer to that of a disciple. It is Alkan's belief that 'no educational relationship could proceed without a simultaneous therapeutic relationship'. His analytic method - 'implication' - sees the roles of analyst and analysand reversed: the analyst says what they think the analysand would say, and the analysand then gives the interpretation they think the analyst would give. According to Ford,'published case histories bear a startling resemblance to those of entirely conventional methods'.

Alkan has several other students/analysands who are despised by other members of the faculty. This is not simply because of their superior manner, but also because of their penchant for playing practical jokes - such as lacing breakfast cereal with peyote - with the aim of persuading the joke's victim they are psychotic.

Ford is under Alkan's supervision for 2 years when Alkan mysteriously disappears, leaving Ford's analysis incomplete. Ford becomes convinced that Alkan is hiding in the West End of London and wishes to be found, communicating his location via coded messages scrawled on the walls of public conveniences. When they eventually meet, the reason for Alkan's flight is revealed to be a prolonged psychotic episode.

Ford next finds work as a research psychologist for a cattle-feed manufacturer who believes in the underlying similarities between cattle and humans. When Men and Cows: Towards the Society of the Future fails to make any impact, Ford moves to Birmingham, researching the psychology of grant applications.

After 5 years in Birmingham, Ford is contacted by Zac Busner, a contemporary from Chelmsford. Busner has founded 'Concept House', a community of clinicians and patients dedicated to redefining the relationship between doctor and patient. Instead of a distinct delineation between these roles, any resident can take on either function at any time. Busner employs Ford to devise and oversee trials of Concept House's effectiveness.

When the trial results prove to be disappointing, Ford finds he has lost interest in the academic study of grant applications and instead wishes to 'hit upon a general explanatory theory of the relation between normal and abnormal psychopathology'. This comes to him suddenly: 'What if there is only a fixed proportion of sanity available in any given society at any given time?'
Reassembling Alkan's students as a research team, Ford identifies a self-contained societal unit on which to test this theory. Levels of sanity are manipulated by the use of chlorpromazine and LSD. Fluctuations are seen in the behaviour of individuals, but as 'the sanity content of the group as a whole remains constant', quantity theory is proven.

Quantity theory and its investigators become famous. The story concludes with an account of the consequences of this, both foreseen and unforeseen.

\section{Themes}

The nature and accessibility of psychotic experience is central to the narrative of The Quantity Theory of Insanity. Notable is the ease with which Self's characters are portrayed as moving in and out of states of mental disorder. Few make it to the end of the story having been entirely 'normal' throughout. Ford's account of his own behaviour is at times sufficiently bizarre that his insight into his own mental state and his reliability as a narrator must be in doubt.

Self does not seek to demonstrate that mental illness does not exist, but satirises approaches that understand it in purely mechanistic terms. According to quantity theory, an individual's sanity is simply a matter of the abundance or lack of mental disorder in his or her environs. The theory's name echoes the quantity theory of money - which had political relevance at the time the story was written - and also nods towards 'balance of nature' theories that consider ecological systems to be predominantly in homeostasis. Self suggests that we are mistaken to seek to understand humans in a similar way and that by strictly dividing mentally 'normal' and 'abnormal' states we create a false dichotomy.

Ford's academic world is presented as facile and self-absorbed. Its practitioners immerse themselves in investigating marginalia and mostly move between undistinguished and indistinguishable institutions. Their research methods are deeply unethical and the distinctions between disciplines vague. Ford's purview as a research psychologist, for instance, is so random - grant applications, 19th-century physiognomic theory, clinical trials in therapeutic communities - that he cannot be more than a dilettante. The privileges granted to university scholarship and scholars' claims to specialist knowledge are thus disputed.

Also questioned in this work is the effectiveness of psychiatrists in treating mental disorder. This topic recurs in Self's subsequent fiction and his stance may owe much to Szasz's well-known critique (Tew 2008). Psychoanalysis, as practised 
by Alkan, is so lacking in validity that analyst and patient roles can be interchanged, with a comparable outcome to the more conventional approach. Similarly, Busner's guiding principle for Concept House is that the division between doctor and patient corresponds to simply 'an unwarranted epistemological assumption', which is hardly an argument for the indispensability of psychiatrists.

Towards the end of the story, the consequences of the fictional theory prove to be mildly prophetic of real-world events. In Ford's theory, people are equated to units of sanity, resulting in the establishment of a government bureau tasked with setting 'a sanity quotient for the whole country'. The recent post-financial crisis focus on measuring well-being in the UK (Office for National Statistics 2012 ) is not so dissimilar.

\section{References}

Barber L (2000) Self control. The Guardian, 11 June (http://www. guardian.co.uk/books/2000/jun/11/fiction.willself).

Hunter Hayes M (2007) Understanding Will Self. University of South Carolina Press.

Office for National Statistics (2012) National Well-being. ONS (http:// www.ons.gov.uk/ons/guide-method/user-guidance/well-being/index. html).

Oyebode F (2010) Interview with writer Will Self part 2. Frontier Psychiatrist (http://frontierpsychiatrist.co.uk/interview-with-writer-willself-part-2).

Tew P (2008) Will Self. In Writers Talk (eds P Tew, F Tolan, L Wilson): 105-24. Continuum. 